\title{
Challenges of Consumer Information Systems Development: The Case of Interactive Television Services
}

\author{
Tuure Tuunanen, Michael D. Myers, and Harold Cassab
}

The University of Auckland, NZ

\begin{abstract}
We suggest that a new type of information system appears to be increasing in importance, that of consumer information systems. Compared with traditional information systems development approaches, where the focus is on improving the efficiency and effectiveness of organizational processes, design for consumer information systems focuses more on the enjoyment, pleasure and purchases of the consumer. We argue that the shift in focus from users to consumers in consumer information systems calls for a significant re-appraisal of our current information systems development methods. Hence, this paper proposes a new research agenda for IS researchers focusing on the development of consumer information systems. We plan to pursue this agenda by primarily using design science research, supplemented by other research methods as needed. The expected contributions include new insights into effective management processes for service design, a better understanding of issues of integration of information systems development practices used to develop consumer information systems, and the development of methods for requirements discovery for service innovation. These three components aim to contribute to a holistic evaluation of consumer information systems.
\end{abstract}

\section{Introduction}

We believe we may be entering a new era of Consumer Information Systems (CIS). Until now most information systems have been developed to improve the efficiency and effectiveness of organizations. However, the rationale for the development of CIS is different: it is to facilitate the enjoyment and pleasure of the consumer. A consumer is defined by the Concise Oxford English Dictionary as:

1. a person or thing that eats or uses something.

Please use the following format when citing this chapter:

Tuunanen, T., Myers, M.D. and Cassab, H., 2008, in IFIP International Federation for Information Processing, Volume 274; Advances in Information Systems Research, Education and Practice; David Avison, George M. Kasper, Barbara Pernici, Isabel Ramos, Dewald Roode; (Boston: Springer), pp. 89-100. 
2. a person who buys goods and services for personal use (Soanes \& Stevenson, 2004).

As can be seen from this definition, the primary meaning of a consumer is of a person who "eats or uses something." The secondary meaning is of person who purchases a service or product. Hence, it is possible for someone to enjoy watching a TV program (consume it) without having to pay for it. In this case, the TV program may actually be "paid for" (indirectly) by advertising. An alternative, of course, is for consumers to purchase TV programs directly (e.g. via a subscription service or pay per view).

It seems to us that the design and development of consumer information systems requires a change in the way we have traditionally thought about users (Lamb \& Kling, 2003). Users have been conceptualized as mostly concerned about the effectiveness and efficiency of work processes. Consumers, on the other hand, are mostly interested in the enjoyment or pleasure associated with "consuming" a product or service. Users have been thought of as passive "users" of the system (as compared with "developers"). Consumers, by contrast, can be much more active in their use of a product or system. This is especially the case with the emergence of new internet-enabled multimedia services where consumers can become participants and co-creators of the television experience or "service". Another difference between users and consumers is that of scale: the number of consumers potentially involved in the development process is very large. Finally, the concept of services (Grönroos, 2007; Menor, Takikonda, \& Sampson, 2002) takes centre stage (as opposed to the idea of creating a distinct IS software product). The focus shifts to innovating, designing and developing internet-enabled services.

This feature of co-creation of the service is facilitated by the social interaction between consumers and producers of services via different feedback mechanisms (such as Facebook-type services). The IP-Television concept, e.g. Joost.com, is one novel way to use the Internet to distribute on-demand digital programming in this fashion. Another example is Mobile Television that merges cellular phones with digital Television broadcasts and rapid feedback mechanisms, like texting. These technological changes are driving the market toward real Interactive Television systems, which will enable consumers not only to participate, but also to be part of the programming i.e. co-creators of CIS.

In this paper, then, we propose a research agenda to investigate the challenges academics and practitioners are likely to face when developing consumer information systems. Our targeted case domain area will be Interactive Television services. We review requirements discovery, information systems development, and service design literature, in order to develop a preliminary framework to drive the proposed research agenda. Finally, we discuss the potential contributions of this paper to IS research and practice. 


\section{Consumer Information Systems: Challenges for Research}

An information system is often defined as the interplay of technology, software and people with the purpose of storing, distributing and communicating information. Others have described an information systems as a system of communication used by members of some human group (Bastek, Tuunanen, \& Gardner, 2008; Beynon-Davies, 2002). Consumer Information Systems have been defined as

A system that uses information technology to provide consumers with services to access, process, and manipulate data over the Internet (Bastek, Tuunanen, \& Gardner, 2008).

Our paper seeks to understand more about CIS: how consumer requirements can be determined; the possible changes required to information systems development processes; and finally, design of consumer targeted services. We review relevant literature and raise a few research challenges below.

\subsection{Requirements Discovery}

Various disciplines have been dealing with the issues surrounding the problem of recognizing the needs of end-users of services and products. In Information Systems the usual way of trying to solve these problems has been to determine the needs of the organizational end-user and then to analyze the data in order to achieve requirements specification of feasible quality (Byrd, Cossick, \& Zmud, 1992; Davis, 1982; Keil \& Carmel, 1995). More recently, however, it has been suggested that users should be reconceptualized as "actors" (Lamb \& Kling, 2003). In marketing, a specific discussion has emerged regarding the issues of developing new products. In this field, the problems have been approached more from a consumers' point of view, and the new product development discipline has been strongly arguing for involving them in the development process (Thomke \& von Hippel, 2002).

Within the software engineering discipline, requirements engineering has been focusing on the issues surrounding the problems in eliciting, analyzing, validating, and managing end-users' requirements (Dubois \& Pohl, 2003; Jarke \& Pohl, 1994). The requirements phase has traditionally been regarded as a phase to "capture" end-user requirements. However, recently this view has started to change. Jirotka and Goguen (1994) have recommended using the term "elicitation" instead of "capture" so as to avoid the suggestion that requirements are out there to be collected simply by asking the right questions. Bergman et al. (2002) suggest that requirements are defined in a political process between the stakeholders. 
Building on this recent work, some IS researchers have suggested that requirements elicitation is a voyage to discovering end-users' needs (Mathiassen, Saarinen, Tuunanen, \& Rossi, 2007), modeling them using suitable techniques, and finally finding consensus among stakeholders in their prioritization. They have further characterized specific risks associated with CIS kinds of development projects, such as the availability of requirements. If we consider developing consumer information systems for global markets or even for regional markets, how we can reach these end-users efficiently? Tuunanen et al (2004) have proposed specific features to be considered for requirements discovery methods. Among others they raise context and reach as important features for such methods. Context of the developed systems always affects the user experience. The question remains, according to Tuunanen et al (2004), how we can understand the user context of consumers. Similarly, they point out that the techniques used should be able to reach multitudes of users outside of the developing organization cost-efficiently. This leads us to propose our first research question (RQ):

RQ1: How is it possible to elicit consumers' requirements effectively?

\subsection{Information Systems Development}

The history of Information Systems development can be characterized as a venture to find solutions for raising the productivity of developers, making systems less defective, or developing systems by techniques that pay more attention to the endusers and their needs (Brooks, 1975). Hirschheim et al. (1995) define information systems development as an "organized collection of concepts, methods, beliefs, values and normative principles supported by material resources". They summarize this as a methodology for Information Systems development. Hence we focus on information systems development (ISD) methods in relation to CIS.

Methods for ISD began with the 'code-and-fix' approach (Boehm, 1988). This method was blamed for many problems, starting with poorly understood requirements and problematical structure of coding and resulting in great expenses when fixes are needed later on (Boehm, 1988). The more structured 'waterfall model' emerged as a systematic, sequential solution to software development problems (Brooks, 1975; Hirschheim, Klein, \& Lyytinen, 2003). With this method, the IS artifact was not delivered until the whole linear sequence had been completed. With the waterfall method, researchers also became more focused on requirements. Determining requirements was considered to be essential and it was suggested to collect them at the start of the development process.

As projects became larger and more complex, such problems as stagnant requirements and badly structured programming started to emerge. Through an overlapping of the development phases (Sommerville, 2001) and through the introduction of the more incremental spiral model (Boehm, 1988; Iivari, 1990a, 
1990b) it was possible to tackle many of the difficulties mentioned above. Recently, different agile methods (Merisalo-Rantanen, Tuunanen, \& Rossi, 2005) have gained recognition. Agile methods return to the idea of focusing on working on the code and minimizing documentation, but at the same time trying to maximize customer satisfaction by involving end-users.

However, there is no agreement in the literature with respect to how users of CIS should be involved in the development process. Participatory design (Clemont \& Besselaar, 1993; Smart \& Whiting, 2001; Vredenburg, Mao, Smith, \& Carey, 2002) and the Scandinavian IS development approach (Iivari \& Lyytinen, 1999; Kautz, 2001) have been suggested as answers, but exact ways of connecting these approaches with the required development methods for CIS are not present in the literature (Tuunanen, 2003). Thus we present our second research question:

RQ2: How is it possible to modify contemporary information systems development methods for consumer information systems?

\subsection{Service Design}

What is a service? Various definitions exist, but usually the IS research literature concentrates on the difference between physical products and services (Penttinen, 2007). The characteristics of services are often addressed by providing sets of attributes inherent to services as contrasted with products (Bastek, Tuunanen, \& Gardner, 2008). Lovelock and Wirtz (2004) capture the essence of services with the notion that a service is any act, performance, or experience that one party can offer to another and that is essentially intangible and does not result in ownership. Traditionally, services have been considered to have the unique characteristics of intangibility, heterogeneity, inseparability of production and consumption, and perishability. Recently, the generalizability of these characteristics has been challenged (Lovelock and Gummeson, 2004), driving the need for contemporary perspectives in service research.

Clearly, it is important to understand consumer requirements in order to deliver a service that meets consumers' needs. Hill et al (2002) suggest that the flow of the service experience and time of flow of the delivered service is important to consumers, as is the emotional responses of consumers to the service. They present a needs-based approach to understand the consumer, which offers a way of conceptualizing consumer evaluations of a service that is different from the usual "met expectations" model (Zeithmal, Parasuraman, and Berry, 1985).

The consumer-based approach thus raises questions about how the service design process should be conducted (Hill et al., 2002; Menor, Takikonda, \& Sampson, 2002). Stuart and Tax (2004) have called for an integrative, holistic service design approach, which would tie together all the areas needed for designing a successful service. Menor et al (2002), however, remain uncertain about the actual 
method needed for new service design. Thus we present our third and final research question:

RQ3: How is it possible for CIS development and requirements discovery methods to take account of the service nature of consumer information systems?

\section{Research Agenda for Consumer Information Systems Development: The Case of Interactive Television Services}

We see fascinating possibilities in terms of understanding how to develop Consumer Information Systems and Interactive TV Services in particular. We have proposed three specific research questions drawn from the literature to set the basis for our research agenda (see Table 1). The focus of study will be to understand consumers' requirements and development methods to support the development of a service. The theoretical framework connecting these is presented in Figure 1 below. We see that the interaction between requirements discovery, information systems development, and service design will drive towards a need for a more holistic approach to consumer information systems development. Thus, our main research objective (RO) will be

RO: The design of a holistic approach to consumer information systems development.

RQ1: How is it possible to elicit consumers' requirements effectively?

RQ2: How is it possible to modify contemporary information systems development methods for consumer information systems?

RQ3: How is it possible for CIS development and requirements discovery methods to take account of the service nature of consumer information systems?

Table 1. Research questions

We will use Interactive Television Services as the domain of the study. Interactive Television Services will see the convergence of current IP-TV, mobile and web based services to one distinct service targeted to mainstream consumers of global markets. We define the concept of interactivity as anything that lets the consumer engage in a dialogue with the provider of the given service enabling him or her to make choices and take actions to influence the content of the provided service (Bastek, Tuunanen, \& Gardner, 2008; Gawlinski, 2003). Currently, the contemporary technology platforms do not support development of such services, 
although platforms for broadcasting high quality video streams do exist ${ }^{1}$. Figure 2 displays some typical applications available today. These usually include electronic programme guides, chat or email clients, or games.

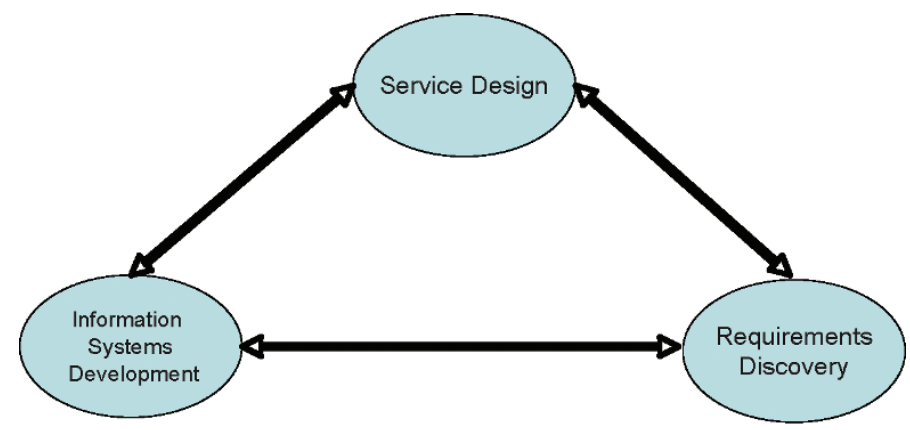

Fig. 1 Challenges of Consumer Information Systems Development

Our vision of Interactive Television Services includes more rich information media, such as two-way video streaming, interaction between participants in real time, and probably a strong social networking context (Peffers \& Tuunanen, 2005). One possible application area could be tertiary education with students participating in a classroom, from campus, home or office with live interaction. Another possibility could be a variation of reality television where participants of the service would affect the course of the service, or more traditionally speaking, the programming on a live Television show. This kind of service will more likely also require active participation and understanding of media production from the developers.
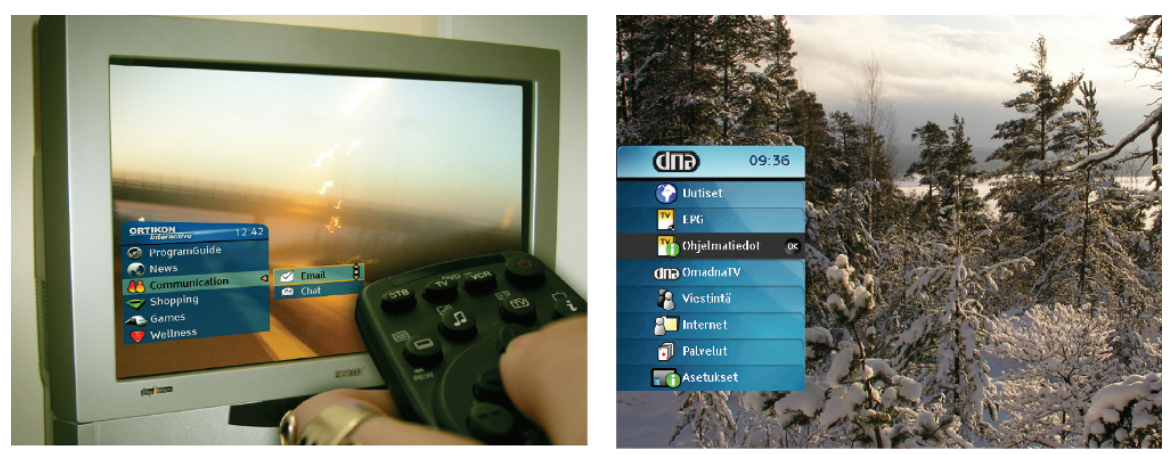

Fig. 2 Industry examples of traditional Interactive Television Services, slightly modified from http://www.ortikon.com/press/

1 Such as platforms by provided www.joost.com, www.redlynx.com and www.matrixstream.com 
We plan to use Design Science Research to drive the research agenda (Hevner, March, Park, \& Ram, 2004; Peffers, Tuunanen, Rothenberger, \& Chatterjee, 2008). The framework is summarized in the figure below. The nominal research process is divided into 1) problem identification, 2) objectives, 3) creation of artifact (in this case Interactive TV platform and Services and a holistic approach to Consumer Information Systems development), 4) demonstration, 5) evaluation, and finally 6) communication of the findings to industry and academia. The framework also provides different entry points for the research. Our research agenda takes the traditional approach of problem-centered initiation. In order to answer specific research questions we intend to complement the Design Science Research Methodology with Action Research (Baskerville \& Myers, 2004). Action research is more oriented towards helping us to understand the managementoriented challenges (as opposed to the "design" of the service). Action research also opens up new interesting possibilities to investigate how to manage and use the newly developed platform.

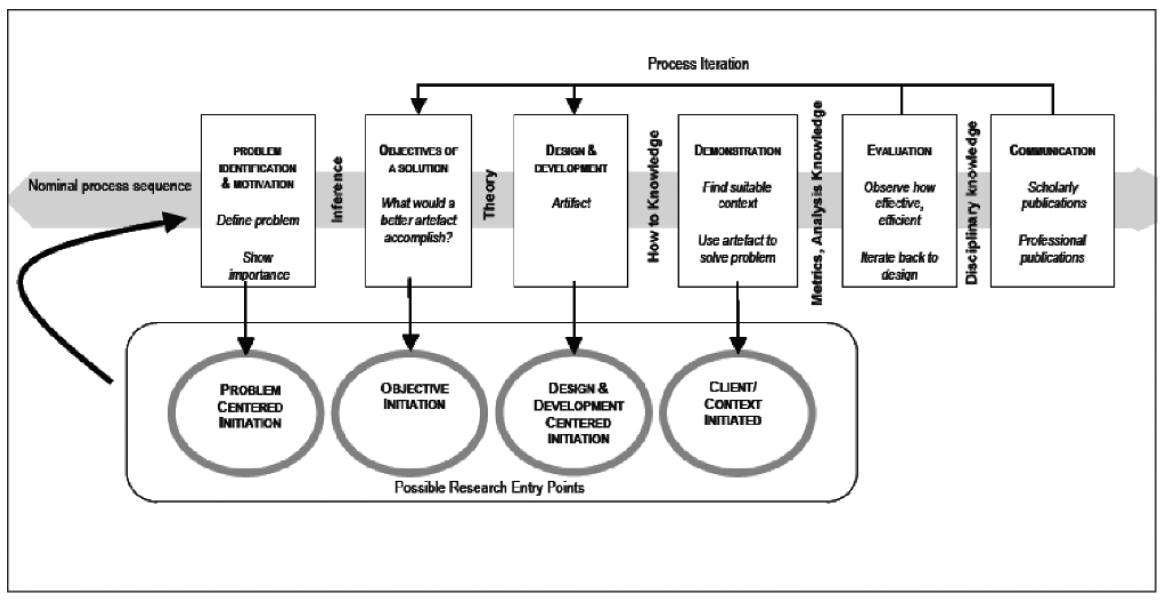

Fig. 3 Design Science Research Methodology, adapted from (Peffers, Tuunanen, Rothenberger, \& Chatterjee, 2008)

The proposed research will be conducted in cooperation with industry and New Zealand universities. We are currently working with the University of Otago (Dunedin) and Victoria University (Wellington) to initiate the development of the Interactive Television Services platform. Furthermore, New Zealand industry participants have welcomed the research agenda. One of our first projects has included a case study of major corporate level players in IPTV (Bastek, Tuunanen, $\&$ Gardner, 2008) and the New Zealand Wireless and Broadband Forum ${ }^{2}$, one of

${ }^{2}$ http://wirelessdataforum.co.nz 
the largest industry associations in New Zealand, is actively involved in the study. Currently, we are actively recruiting media industry participants with whom we have been in talks e.g., TVNZ and Weta.

\section{Research in progress}

The proposed research is currently under way and we are at the 'problem identification' stage of design science research methodology (Peffers, Tuunanen, Rothenberger, $\&$ Chatterjee, 2008). More specifically, we are in the middle of the requirements discovery process to understand potential end-user requirements for Interactive Television Services for tertiary education. For this purpose we are using an adaptation of wide audience requirements engineering method (Tuunanen, Peffers, \& Gengler, 2004), which incorporates an in-depth interviewing technique called laddering.

The laddering technique is based on the Personal Construct Theory (Kelly, 1955). With laddering, analysts can discover the implicit requirements of potential users of innovative products or services (Peffers \& Tuunanen, 2005; Tuunanen, 2003; Tuunanen, Peffers, \& Gengler, 2004). Laddering uses open-ended questioning with simple probing questions like "what would you like to have in this service" or "why this feature would be important to you" to discover features of the developed artifact. The follow-up questioning in turn opens up the understanding of why these provide value to the users. This process creates chains of ladders, which can be used for analyzing the priority of requirements.

Our current project uses potential lead-users (Rogers, 1995; von Hippel, 1986) of Interactive TV Services for tertiary education, namely first and second year undergraduate students in The University of Auckland Business School. Our initial target is to get approximately thirty laddering interviews done by end of March 2008 and do the preliminary analysis done by April. The pilot study tries to set objectives for a more elaborate way of discovering consumers' requirements and thus creates the basis for providing answers to our first research questions and eventually creation of the new requirements discovery method. We expect to have initial results to report in July-August 2008.

\section{Conclusion}

The paper has proposed a research agenda for investigating challenges of developing Consumer Information Systems. More specifically, we have focused on understanding how the change in concept of "end-user" in traditional information systems development methods to "consumer" potentially affects the overall design of the more service-oriented aspects of CIS. 
We see the intersection of requirements discovery (Mathiassen, Saarinen, Tuunanen, \& Rossi, 2007; Tuunanen, 2003), information systems development, and service design (Grönroos, 2007; Menor, Takikonda, \& Sampson, 2002; Stuart \& Tax, 2004) as a intriguing area of future research. We have suggested a set of research questions in order to understand how to best manage the CIS development process.

We have proposed Design Science Research (Peffers, Tuunanen, Rothenberger, $\&$ Chatterjee, 2008) as our primary research method. Our intention is to complement this approach with action research (Baskerville \& Myers, 2004). Action research has been considered to be a good complement to Design Science Research (Järvinen, 2007; Rossi \& Sein, 2003).

We have chosen one of the emerging application areas of CIS as our research domain. Interactive Television Services are just starting to become available. Our intention is help the TV industry to push the current envelope of provided services and create an Interactive Television Service platform for consumers. Furthermore, we expect that our action research co-operation with New Zealand industry will create further interesting uses for the developed platform.

The main academic contribution of our proposed research agenda lies in its contribution to the development of Consumer Information Systems. We propose integrating Service Design, information systems development, and requirements discovery practices. Furthermore, we see that we will be able to contribute by developing new ways for requirements discovery for consumer markets. Finally, the interactive nature of the developed services opens interesting research possibilities. How the change from passive to active participants, or even co-creation, changes "user" or "consumer" behavior is an interesting question.

Practical contributions for industry and education will emerge from building a test environment and prototype systems. One such possibility would be to use the local student population to build and create content for a national interactive TV IP-based network. After the piloting phase we could extend this nationally in New Zealand. This "live" Interactive TV media laboratory would enable New Zealand firms to trial Interactive TV services.

\section{References}

Baida, Z., Gordijn, J., \& Omelayenko, B. (2004). A shared service terminology for online service provisioning. Paper presented at the 6th international conference on electronic commerce, Delft, The Netherlands.

Baskerville, R., \& Myers, M. (2004). Special Issue on Action Research in Information Systems: Making IS Research Relevant to Practice - Foreword. MIS Quarterly, 28(3), 329-336.

Bastek, M., Tuunanen, T., \& Gardner, L. (2008). Consumer Information Systems Service Families (pp. 10): The University of Auckland Business School. 
Bergman, M., King, J. L., \& Lyytinen, K. (2002). Large Scale Requirements Analysis Revisited: The Need for Understanding the Political Ecology of Requirements Engineering. Requirements Engineering, 7(3), 152-171.

Beynon-Davies, P. (2002). Information systems - an introduction to informatics in organizations. Houndmills: Palgrave.

Boehm, B. (1988). A Spiral model of software development and enhancement. IEEE Computer, 21(5), 61-72.

Brooks, F. (1975). The Mythical Man Month: Essays on Software Engineering. Reading, Mass, USA: Addison-Wesley.

Byrd, T. A., Cossick, K. L., \& Zmud, R. W. (1992). A Synthesis of Research on Requirements Analysis and Knowledge Acquisition Techniques. MIS Quarterly, 16(1), 117-138.

Clemont, A., \& Besselaar, O. (1993). A Retrospective look at PD projects. Communications of the ACM, 36(4), 29-39.

Davis, G. (1982). Strategies for information requirements determination. IBM Systems Journal, 21(1), 4-31.

Dubois, E., \& Pohl, K. (2003). RE 02: A major step toward a mature requirements engineering community. Ieee Software, 20(1), 14-15.

Gawlinski, M. (2003). Interactive television production. Oxford: Focal Press.

Grönroos, C. (2007). Service management and marketing - customer management in service competition. Chichester: Wiley.

Hevner, A. R., March, S. T., Park, J., \& Ram, S. (2004). Design Science in Information Systems Research. MIS Quarterly, 28(1), 75-105.

Hill, A. V., Collier, D. A., Froehle, C. M., Goodale, J. C., Metters, R. D., \& Verma, R. (2002). Research opportunities in service process design. Journal of Operations Management, 20(2), 189-202.

Hirschheim, R., Heinzl, K. K., \& Lyytinen, K. (1995). Information Systems Development and Data Modelling: Cambridge University Press.

Hirschheim, R., Klein, H. K., \& Lyytinen, K. (2003). Information Systems Development and Data Modeling : Conceptual and Philosophical Foundations: Cambridge University Press.

Iivari, J. (1990a). Hierarchical Spiral Model for Information-System and Software- Development .1. Theoretical Background. Information and Software Technology, 32(6), 386-399.

Iivari, J. (1990b). Hierarchical Spiral Model for Information-System and Software- Development .2. Design Process. Information and Software Technology, 32(7), 450-458.

Iivari, J., \& Lyytinen, K. (1999). Research on Information Systems Development in Scandinavia- Unity in Plurality. Scandinavian Journal of Information Systems, 10(1-2), 135-185.

Jarke, M., \& Pohl, K. (1994). Requirements Engineering in 2001 - (Virtually) Managing a Changing Reality. Software Engineering Journal, 9(6), 257-266.

Jirotka, M., \& Goguen, J. (Eds.). (1994). Requirements Engineering: Social and Technical Issues: Academic Press.

Järvinen, P. (2007). Action Research is Similar to Design Science. Quality \& Quantity, 41(1), 37-54.

Kautz, K. (2001). Trends in the Research on Software Process Improvement in Scandinavia. Scandinavian Journal of Information Information Systems, 13, 3-6.

Keil, M., \& Carmel, E. (1995). Customer Developer Links in Software-Development. Communications of the ACM, 38(5), 33-44. 
Kelly, G. A. (1955). The Psychology of Personal Constructs. New York: W W Norton \& Company.

Lamb, R., \& Kling, R. (2003). Reconceptualizing Users as Social Actors in Information Systems Research. MIS Quarterly, 27(2), 197-235.

Mathiassen, L., Saarinen, T., Tuunanen, T., \& Rossi, M. (2007). A Contigency Model for Requirements Development. Journal of Association of Information Systems, 8(11), 569-597.

Menor, L. J., Takikonda, M. V., \& Sampson, S. E. (2002). New service development: areas for exploitation and exploration. Journal of Operations Management, 20(2), 135-157.

Merisalo-Rantanen, H., Tuunanen, T., \& Rossi, M. (2005). Is Extreme Programming Just Old Wine in New Bottles: A Comparison of Two Cases. Journal of Database Management, 16(4), 4161.

Peffers, K., \& Tuunanen, T. (2005). Planning for IS applications: a practical, information theoretical method and case study in mobile financial services. Information \& Management, 42(3), 483-501.

Peffers, K., Tuunanen, T., Rothenberger, M., \& Chatterjee, S. (2008). A Design Science Research Methodology for Information Systems Research. Journal of Management Information Systems, 24(3), 45-78.

Penttinen, E. (2007). Transition from products to services within the manufacturing business. Unpublished Doctoral dissertation, Helsinki School of Economics, Helsinki.

Rogers, E. M. (1995). Diffusion of Innovations (4th ed.). New York: The Free Press.

Rossi, M., \& Sein, M. K. (2003). Design research workshop: a proactive research approach. Paper presented at the Conference Name|. Retrieved Access Date|. from URL|.

Smart, K. L., \& Whiting, M. E. (2001). Designing Systems that support learning and use: A Customercentered approach. Information \& Management, 39(3), 177-190.

Soanes, C., \& Stevenson, A. (Eds.). (2004). Concise Oxford English Dictionary (11th ed.). Oxford: Oxford University Press.

Sommerville, I. (2001). Software Engineering (6th ed.): Addison-Wesley.

Stuart, F. I., \& Tax, S. (2004). Toward an integrative approach to designing service experiences Lessons learned from theatre. Journal of Operations Management, 22(6), 690-627.

Thomke, S., \& von Hippel, E. (2002). Customers as innovators - A new way to create value. Harvard Business Review, 80(4), 74-+.

Tuunanen, T. (2003). A New Perspective on Requirements Elicitation Methods. JITTA : Journal of Information Technology Theory \& Application, 5(3), 45-62.

Tuunanen, T., Peffers, K., \& Gengler, C. (2004). Wide Audience Requirements Engineering (WARE): a Practical Method and Case Study (No. W-378). Helsinki: Helsinki School of Economics.

von Hippel, E. (1986). Lead Users: A Source of Novel Product Concepts. Management Science, 32(7), 791-805.

Vredenburg, K., Mao, J., Smith, P. W., \& Carey, T. (2002). A survey of user-centered design practise. CHI Letters, 12(2).

Zeithaml, V. A., Parasuraman, A., \& Berry, L. L. (1985). Problems and strategies in services marketing. Journal of Marketing, 49(2), 33-46. 